Journal of Accident and Emergency Medicine 1994 11, 97-100

\title{
The tragedy at St Peter's Field, Manchester, 16 August 1819*
}

\author{
J. MARROW
}

Accident and Emergency Department, Arrowe Park Hospital, Upton, Wirral, Merseyside

\section{SUMMARY}

In 1819, in Manchester in the north of England, 12 people died and approximately 630 were injured when cavalry were used to disperse an orderly political demonstration. Injuries sustained in the crush exceeded wounds directly from the soldiers' swords. The pattern of injuries is described and some aspects of official, medical and popular reaction to the incident are discussed.

Key words: disaster, history, Manchester, riot, trauma

\section{INTRODUCTION}

In 1990, the British Association for Accident and Emergency Medicine met in Manchester. A major incident resulting in large numbers of casualties took place less than a mile from the conference hotel, over 170 years before the meeting, on 16 August 1819.

Industrial Manchester was already growing fast by that date. The first steam locomotive had been constructed, however, the railway between Liverpool and Manchester was not to be opened for another 11 years. Manchester was one of the first cities outside London to have an Infirmary; it was established in $1752 .^{1}$

\section{THE INFIRMARY'S RESPONSE}

The Infirmary's Board of Management recorded discussion of the events following the disaster. ${ }^{2}$

Correspondence:

J. Marrow,

Consultant in

Accident and

Emergency Care,

Accident and

Emergency

Department, Arrowe

Park Hospital, Upton, Wirral, Merseyside L49 5PE, UK
There was no detail of the injuries, not even a simple record of numbers of casualties treated. The Board's concern was to refute allegations of prior knowledge of the disaster and of refusal to treat the injured. These allegations were published in various newspapers in the weeks following 16 August.

* This article is based on a paper read at the Annual Scientific Meeting of the British Association for Accident and Emergency Medicine held in Manchester in April 1990.
For example, the Manchester Observer stated:

Every patient in the Infirmary was literally turned out, which could possibly be done, preparatory to the horrible butchery which took place on 16th instant, in order to prepare for the wounded which might be brought there for surgical aid. The fact is almost conclusive that something was previously arranged, of which the fruits were seen on that bloody day.

(Manchester Observer, 28 August 1819)

It seems a bit unfair. We might think it only prudent to try and empty a few additional beds before an event quite likely to lead to civil disorder. It would not necessarily indicate a plot with the repressive government.

Some accusations were more specific:

A poor man - cut down on 16 August - in pressure of the crowd, occasioned by the charge of the cavalry, had his shoulder dislocated, his elbow crushed and his head severely cut.

At the Infirmary... when it came to be his turn to be examined, was thus addressed by one of the surgeons: 'You won't go to another meeting for reform, I warrant.' 'Yes, I shall,' was the reply, 'if I can recover. The last meeting has shown me more strongly than ever the necessity for reform.'

The consequence was that he was turned out of the infirmary and in that wretched state forced to make his way home. . seven miles. . . as best he could.

(The Times, 14 September 1819)

Another paper, The Manchester Courier, reported that both his shoulders were dislocated, one arm was broken and that he had cuts to head and forehead. The Infirmary Board denied the charge indignantly.

\section{THE MEETING}

Notices of a mass meeting to be held in St Peter's Field in central Manchester had been posted widely. 
The meeting was to be addressed by a renowned popular speaker, Henry Hunt, sometimes known as 'Orator' Hunt. His name on the posters ensured a large turn-out.

The purpose of the meeting was to secure reform of the parliamentary system with proper representation for the growing industrial towns of the north. The Radical Reformers, as they were called, did sometimes borrow ideas from the recent French Revolution. The committee of magistrates who were responsible for law and order in Manchester were extremely nervous by the time 16 August dawned.

There was not yet any regular police force. The magistrates had at their disposal a small body of about 30 watchmen and patrolmen, under the direction of an official called the Boroughreeve, two unpaid constables and one Deputy Constable. When trouble was anticipated special constables were sworn in. For the meeting on 16 August between 400 and 500 had been assembled. ${ }^{3}$

It was also quite usual for the authorities to call upon the army for support in maintaining order. Only 2 years previously the army had been involved in suppressing a similar meeting in the same open space. That operation, in the hands of an experienced general, had passed without any bloodshed at all. Unfortunately there was an important race meeting in York on the 16 August, 1819. With permission from the Home Office the armed forces in Manchester, more than 1000 men, were left in the charge of the general's deputy.

The map shows how the military forces were deployed. Most of the cavalry were several blocks away from St Peter's Field, towards the Irwell. A similar distance away, eastward, beyond the church, there was a detachment of volunteer Yeomanry Cavalry. They were raised at the expense of a local landowner, richly uniformed but poorly trained. Recruited from the petit bourgeousie,

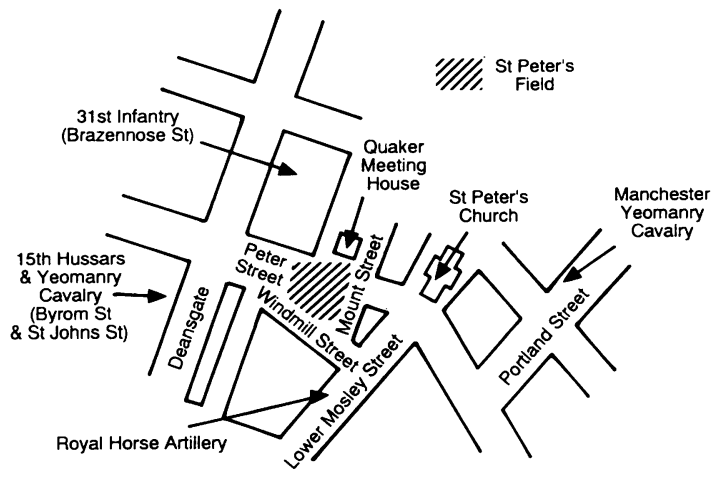

Fig. 1. Map of the area around St Peter's Field on 16 August 1819. business-men and small landowners, they were a force intended for use in defending the political status quo. Neither horses nor men had experience of action off the parade ground.

People came to the meeting from towns and villages around Manchester as well as from the city itself. Some contingents were led by bands and banners. As far as we can tell they were unarmed and certainly they brought women and children with them to hear the famous speaker. ${ }^{4}$

The magistrates gathered while the Field was still empty and nervously watched from the first floor of a house in Mount Street. Apparently what alarmed them was the orderliness and quiet patience with which the crowd waited in the sun for the meeting to start.

Estimates of the size of the crowd range from 30000 to 150000 , the lower figure is the more probable. ${ }^{5}$ When the carriage arrived carrying Henry Hunt and his party the magistrates could bear it no longer and issued warrants for the arrest of the speakers. The special constables were by now engulfed in the huge crowd so notes were sent to the two main cavalry formations requesting assistance.

It seems that word reached the detached force of inexperienced Yeomanry cavalry first. They raced to St Peter's Field with drawn sabres. They had killed one civilian, an infant knocked from her mother's arms, before they reached the assembly. ${ }^{6}$

Once the horsemen were in the crowd it is no wonder there was a panic, adding to the injuries from the sabres and the horses hooves. When the Hussars arrived, moments later, there was no room for the skilful manoeuvering which had saved the day in 1817 . They went into action to rescue the

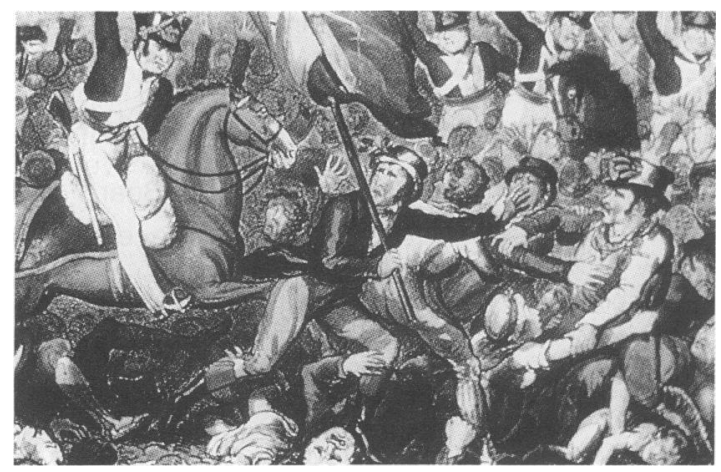

Fig. 2. The 'Peterloo' massacre. Detail of an aquatint, possibly by G. Cruikshank. Published by R. Carlile, London, 1 October 1819. Reproduced by kind permission of the Local Studies Library of the Manchester Central Library. 
The St Peter's field massacre
Yeomanry and clear the field. The arrests proceeded and the platform party were marched off to the New Bailey Prison. It was all over in 20 minutes.

Newspaper reports gave the Government's official reaction. The Prince Regent commanded:

that Royal Satisfaction be expressed at the prompt decisive measures of the magistrates for the preservation of the public tranquility.

(The Times, 21 August 1819).

He also sent special thanks to the Yeomanry. The reality of the disaster was partly revealed,

Now ensues a most painful and melancholy part of our recital. The necessary ardour of the troops in the discharge of their duty has led to some fatal and many serious accidents. (The Times, 19 August 1819)

\section{THE INJURIES}

Early reports mentioned eight or 10 dead with about 50 wounded (The Times, 19, 21 August 1819). On 16 and 17 August there were 63 casualties admitted to the Infirmary, of whom three died. Eleven people were admitted in the subsequent week. It was difficult to get an overall picture. The injured came from many parts of the region and some delayed reporting their injuries because they were frightened of the consequences. $^{6}$

On 3 September, The Times published a list, giving the names of 198 persons injured, which had been collected by a lawyer with radical sympathies. The author classified the list by sex and by method of injury. There was also a primitive attempt at severity scoring, ' $b$ ' followed many of the names indicating that the person was 'badly hurt'.

Other detailed lists of the injured were published later. Table 1 shows the likely toll of death and injury of the event which came to be known as 'the Peterloo Massacre'. 'Peterloo' came from the name of the Field and from the recent battle at Waterloo, in which the 15th Hussars had actually fought.

By combining the data from all the lists, the modes of injury can be analysed. With swords wielded by

Table 1. Numbers of injuries and deaths

\begin{tabular}{lr}
\hline Under 16 & 8 \\
Females & 165 \\
Males & 461 \\
Sex not recorded & 4 \\
Total injuries & \\
Deaths & \\
\hline
\end{tabular}

Table 2. Nature of the recorded injuries

\begin{tabular}{lr}
\hline Sabre and other cuts & 215 \\
Head wounds & 90 \\
Fatalities & 7 \\
Bayonetted or stabbed & 16 \\
Trampled or crushed & 357 \\
Fatalities & 6 \\
Beaten & 44 \\
Fatality & 1 \\
Unspecified & 105 \\
\hline
\end{tabular}

Many patients suffered combinations of injuries, e.g. 103 were sabred and also trampled, beaten or bayonetted.

men on horseback, the predominance of head wounds is no surprise. Perhaps it is not surprising either, that more were hurt from the crush and panic than from the direct effects of the swords. The constables caused relatively few injuries. On foot and in the crowd they were not at an advantage and at least two were amongst the dead.

The smaller number of females injured than men probably does not reflect particular discrimination or chivalry on the part of the soldiers but rather the fact that there were fewer women in the crowd than men.

We can be quite precise about the deaths, as inquests of a sort were held in cases of violent death. The proceedings did not always have the impartiality that would be expected now.

The total number of deaths quoted varies, depending on which should be included. The author's list does not include a man who died on the evening of 16 August, elsewhere in Manchester, as infantry units attempted to suppress continuing protests. It does include those who died actually in St Peter's Field and also those who died later as a result of injuries sustained there.

Table 3. The causes of death

\begin{tabular}{lr}
\hline Sabre wounds & 5 \\
Sabred and trampled & 2 \\
Trampled by horses & 3 \\
Crushed in a cellar & 1 \\
Crushed and beaten & 1 \\
Total & 12 \\
\hline
\end{tabular}

\section{RELIEF OF THE SUFFERERS}

Funds were collected in $\mathbf{1 8 1 9}$ to relieve the suffering which followed Peterloo. The accounts which were 


\section{J. Marrow}

kept by those responsible for these funds are a fascinating commentary on both the pattern of injuries sustained and the social attitudes of those days. In the John Rylands Library of the University of Manchester is a leather-bound pocket book in which an unknown writer recorded the details of 418 beneficiaries of the Metropolitan and Central Committee for the Relief of the Manchester Sufferers. $^{7}$

The writer notes social detail as well as brief accounts of injuries in a clear hand. Some examples follow.

John Brierley might have deserved more than the 20 shillings awarded as compensation for injuries sustained when he was 'thrown down and trampled on by the cavalry and crushed by the crowd'. The writer also notes that 'He had some bread and cheese in his hat which saved head from being cleft with the stroke of a sabre.'

Jane Ditchfield, a widow, received 25 shillings to help with her five children for 5 weeks while she recovered from 'a severe sabre cut in the left leg'. This makes an odd contrast with Isaac Murray who was awarded 60 shillings because he 'was a fortnight in prison'. No physical injury is mentioned, however, the writer states that he was 'a genteel young man, a poet'.

Samuel Jackson lost a leg as a result of a gunshot on the evening after the meeting. He was probably nothing to do with the disturbances but 'was going to see his aunt'. He received $£ 13$ in total, the highest amount awarded. James Lees sustained 'two desperate cuts on the head, one 5 inches long by one of the 15th Hussars. Taken to the Infirmary and after being strped [sic] one of the junior surgeons ordered him to a bed and put a ticket with his name on it. Dr Ransome asked him if he had enough of Manchester meetings and on his reply in the negative he was told there was no room for him'. The patient did not have even one dislocated shoulder and it would seem that politics influenced the behaviour of at least one Manchester doctor.

\section{CONCLUSION}

The year 1819 was about the time when the grandparents of the oldest patients we now see were born. The street-names of central Manchester have altered little, but almost all the buildings are much more recent. St Peter's Field itself was all built over by 1850 . The Free Trade Hall now occupies part of the site.

The events of 16 August 1819 had one consequence which has survived. The Times newspaper had sent a reporter to St Peter's Field. His name was John Tyas and to make sure that he heard what the speakers said, he got himself a place right on the hustings. When the trouble began Tyas was locked up with the speakers and could not send his story. Watching the demonstration that day was a young cotton merchant called John Edward Taylor. He felt sympathy for the Reformers and sent an account of the day to the London papers. Not having received dispatches from their regular reporter, The Times printed Taylor's account. Taylor stayed in journalism and in 1821 founded the Manchester Guardian. Now called The Guardian his newspaper still seeks to continue its founder's liberal ideals.

\section{ACKNOWLEDGEMENTS}

The author wishes to thank the staff of the John Rylands Library of Manchester University for their help in preparing this paper. I am grateful to the Librarian of the Local Studies Library of the Manchester Central Library for permission to reproduce the contemporary print of the scene in St Peter's Field. Two papers from the Manchester Region History Review are cited below but the Special Issue published in 1989 about the 'Peterloo' massacre contained much useful information for which I should like to thank its editors.

\section{REFERENCES}

1. Duffield H.G. (1850) The Stranger's Guide to Manchester. Richardson, Manchester.

2. Renaud F. (1898) A Short History of the Rise and Progress of the Manchester Royal Infirmary From the Year 1752 to 1877. J.E. Cornish, Manchester.

3. Reid R. (1989) The Peterloo Massacre. Heinemann, London.

4. Dunckley H. (1983) Bamford's Passages in the Life of a Radical and Early Days. Fisher Unwin, London.

5. Bee M. \& Bee W. (1989) The casualties of Peterloo. Manchester Region History Review 3(1) 43-49.

6. Marlowe J. (1989) The day of Peterloo. Manchester Region History Review 3(1) 3-7.

7. Account Book of the Metropolitan and Central Committee Appointed for the Relief of the Manchester Sufferers (1820), London. 